\title{
EDUKASI ALAT PELINDUNG DIRI SAAT DISPENSING OBAT SEBAGAI UPAYA PENCEGAHAN VIRUS MELALUI PEMBAGIAN BOOKLET
}

\author{
Ramdhani M Natsir'1), Muhammad Hasan W'1), Frenky Aipassa'1) \\ 1)Program Studi Teknologi Laboratorium Medis, Poltekkes Kemenkes Maluku, Ambon, Indonesia \\ Corresponding author : Ramdhani M Natsir \\ E-mail : Ramdhani_apt@yahoo.com
}

Diterima 13 Juli 2021, Direvisi 25 Juli 2021, Disetujui 26 Juli 2021

\begin{abstract}
ABSTRAK
Virus merupakan mikroorganisme pathogen dan tersebar di berbagai penjuru dunia. Meluasnya penyebaran virus di Indonesia berdampak terhadap semua bidang terutama bidang usaha yang menawarkan jasa atau bekerja di sarana pelayanan kefarmasian. Virus ini bisa menyerang siapa saja. Meluasnya penyebaran virus di Indonesia berdampak terhadap semua bidang terutama sekali bidang usaha yang menawarkan jasa atau bekerja di sarana pelayanan kefarmasian. Oleh karena itu untuk meminimalisir penularan penyebaran virus banyak hal yang harus diperhatikan oleh tenaga kesehatan. Tujuan kegiatan ini adalah untuk melakukan upaya perlindungan diri saat dispensing obat dari pencegahan penyebaran virus dalam memberikan pelayanan kefarmasian. Kegiatan ini dilaksanakan dalam bentuk penyuluhan melalui media booklet. Pada kegiatan ini dilakukan tahapan pre dan post test sebelum dan setelah dilakukan penyuluhan. Secara statistik hasil dari pelaksanaan pre test dan post test diuji analisis dengan menggunakan analisis paired sample t-test dengan dengan hasil perolehan adalah nilai sig (2-tailed) sebesar $0,000<0,05$, maka terdapat perbedaan yang signifikan antara pre test dan post test. Hal ini mengindikasikan bahwa edukasi alat pelindung diri saat dispensing obat sangat mempengaruhi tingkat pengetahuan masyarakat. Terjadi peningkatan pengetahuan setelah dilakukan kegiatan penyuluhan. Hal ini mengindikasikan bahwa pemberian edukasi alat pelindung diri saat dispensing obat sangat mempengaruhi tingkat pengetahuan tenaga kefarmasian.
\end{abstract}

Kata kunci: alat pelindung diri; virus

\begin{abstract}
Viruses are pathogenic microorganisms and are spread all over the world. The widespread spread of the virus in Indonesia has an impact on all fields, especially the business sector that offers services or works in pharmaceutical service facilities. This virus can attack anyone. The wide spread of the virus in Indonesia has an impact on all fields, especially the business sector that offers services or works in pharmaceutical service facilities. Therefore, to minimize the transmission of the spread of the virus, there are many things that must be considered by health workers. The purpose of this activity is to carry out self-protection efforts when dispensing drugs from preventing the spread of the virus in providing pharmaceutical services. This activity is carried out in the form of counseling through booklet media. In this activity, pre and post test stages were carried out before and after counseling. Statistically, the results of the pre-test and post-test were analyzed using paired sample t-test analysis with the results obtained is a sig (2-tailed) value of $0.000<0.05$, so there is a significant difference between pre-test and post-test. . This indicates that education on personal protective equipment when dispensing drugs greatly affects the level of public knowledge. There was an increase in knowledge after the counseling activities were carried out. This indicates that the provision of personal protective equipment education when dispensing drugs greatly affects the level of knowledge of pharmacists.
\end{abstract}

Keywords: personal protective equipment; dispensing; virus

\section{PENDAHULUAN}

Virus merupakan mikroorganisme pathogen dan tersebar di berbagai penjuru dunia. Virus ini cenderung bersifat parasit. Virus dapat menginfeksi makhluk hidup, mulai dari manusia, hewan, tumbuhan, jamur, bahkan bakteri. Infeksi virus tersebut banyak menimbulkan akibat yang fatal.
Virus juga tidak bisa bereplikasi (memperbanyak diri) tanpa menumpangi organisme lain. Virus ini bisa menyerang siapa saja, baik bayi, anak-anak, orang dewasa, lansia, ibu hamil, maupun ibu menyusui (Triguno et al., 2020).

Meluasnya penyebaran virus di Indonesia berdampak terhadap semua bidang 
terutama sekali bidang usaha yang menawarkan jasa atau bekerja di sarana pelayanan kefarmasian Oleh karena itu untuk meminimalisir penularan penyebaran virus banyak hal yang harus diperhatikan oleh tenaga kesehatan. Acuan penerapan langkah langkah yang bisa diterapkan adalah melakukan pencegahan penyebaran virus di apotek dan melakukan upaya perlindungan untuk tenaga kefarmasian dari penularan virus (Kemenkes, 2020). Data terbaru dari Badan Nasional Penanggulangan Bencana didapatkan sebanyak 803 orang apoteker terkonfirmasi Covid-19 dengan 640 orang dinyatakan sembuh dan 6 orang meninggal. Selain itu, terdata 283 orang kontak erat dan 723 orang melakukan isolasi mandiri. Banyaknya jumlah fasilitas farmasi di kota ambon berdasarkan badan pusat statistik kota ambon pada tahun 2019 sejumlah 115 apotek yang terdiri dari beberapa tenaga kefarmasian meliputi apoteker dan tenaga teknis kefarmasian diwajibkan untuk memakai alat perlindungan diri untuk menjaga mereka agar tetap aman dari virus. Tenaga kefarmasian di apotek merupakan tenaga kesehatan garis depan dalam memberikan obat dan paling berisiko terutama bagi orang yang baru mengalami gejala demam dengan virus corona. Menurut Surat edaran yang dikeluarkan oleh Menteri Kesehatan dengan nomor HK.02.01/MENKES/335/2020 tentang Protokol Pencegahan Penularan Covid-19 di Tempat Kerja Sektor Jasa dan Perdagangan (Area Publik) dalam Mendukung Keberlangsungan Usaha, protokol pencegahan penularan virus ini berlaku bagi pengelola tempat kerja, pelaku usaha, pekerja, pelanggan/konsumen dan masyarakat yang terlibat pada sektor jasa dan perdagangan (area publik) diharapkan meminimalisir resiko potensi penularan virus akibat berkumpulnya sejumlah atau banyak orang dalam satu lokasi. (Kementerian Kesehatan RI, 2020)

Media booklet yang digunakan berisi mengenai desain infografis yaitu informasiinformasi yang diperlukan supaya masyarakat mengetahui cara untuk menanggulangi atau meminimalisir penyebaran virus Corona di lingkungan apotek. (Kusuma Putra et al., 2020). Media booklet yang menarik sebagai media untuk meningkatkan pengetahuan dan sikap masyarakat (Aziza et al., 2020). Dengan adanya booklet maka perlu diberikan edukasi alat pelindung diri saat dispensing obat sebagai salah satu kegiatan dalam melakukan pelayanan kefarmasian.

Tempat lokasi kegiatan pengabdian masyarakat ini adalah Apotek Century yang terletak di Jalan Wolter Monginsidi, Passo, Kota
Ambon. Jarak tempuh apotek century ke kampus prodi teknologi laboratorium medis 7 $\mathrm{km}$. Meluasnya penyebaran virus berdampak terhadap apotek century yang menawarkan jasa atau bekerja di sarana pelayanan kefarmasian. Adanya 1 kasus tenaga kefarmasian di apotek century kota ambon yang terkena virus corona tanpa mengalami gejala menyebabkan perlunya alat pelindung diri dalam melakukan pelayanan kefarmasian. Sasaran yang diharapkan dalam pengabdian ini adalah tenaga kefarmasian untuk melakukan upaya perlindungan diri saat dispensing obat dari pencegahan penyebaran virus dalam memberikan pelayanan kefarmasian.

Berdasarkan permasalahan yang ada maka kami sebagai tim pengabdi berinisiatif melakukan edukasi alat pelindung diri saat dispensing obat sebagai upaya pencegahan penyebaran virus melalui pembagian booklet di apotek. Dispensing terdiri dari penyiapan, penyerahan dan pemberian informasi obat. (Kementerian Kesehatan RI, 2014). Dalam hal penyiapan obat, penyerahan dan pemberian informasi obat, tenaga kefarmasian wajib dalam keadaan bersih/aseptik saat melakukan pelayanan kefarmasian. (Rachmawati et al., 2013). Dengan adanya booklet merupakan salah satu bentuk edukasi alat pelindung diri tenaga kefarmasian untuk meminimalkan kontak dengan pelanggan sebagai upaya pencegahan penyebaran virus (Kementerian Kesehatan RI, 2020) Adapun tujuan khusus kegiatan ini adalah:

a. Perlindungan diri tenaga kefarmasian dalam memberikan pelayanan kefarmasian

b. Peningkatan pengetahuan pada tenaga kefarmasian tentang edukasi alat pelindung diri saat dispensing obat dalam pelayanan kefarmasian

\section{METODE}

Metode yang digunakan pada pengabdian kepada masyarakat ini adalah penyuluhan edukasi alat pelindung diri saat dispensing obat melalui media booklet. Kegiatan edukasi alat pelindung diri saat dispensing obat di apotek century dilaksanakan untuk meningkatkan pemahaman tentang alat pelindung diri sebagai upaya pencegahan virus. Mitra yang dilibatkan adalah manager, apoteker dan tenaga teknis kefarmasian yang bekerja di apotek century kota ambon. Jumlah peserta yang terlibat adalah 10 orang. Kegiatan ini dibagi menjadi tiga tahap yaitu tahap pertama pre test sebelum dilakukan penyuluhan untuk mengetahui tingkat pengetahuan awal tentang alat pelindung diri, tahap kedua penyuluhan tentang pengenalan edukasi alat pelindung diri 
terutama saat dispensing obat dan dan tahap terakhir post test setelah dilakukan penyuluhan sebagai evaluasi.

\section{HASIL DAN PEMBAHASAN}

Peserta yang mengikuti kegiatan pengabdian kepada masyarakat adalah masyarakat yang terdiri dari store manager, apoteker pengelola apotek dan tenaga teknis kefarmasian berjumlah 20 orang yang bekerja diapotek century seperti yang terlihat pada Gambar 1.

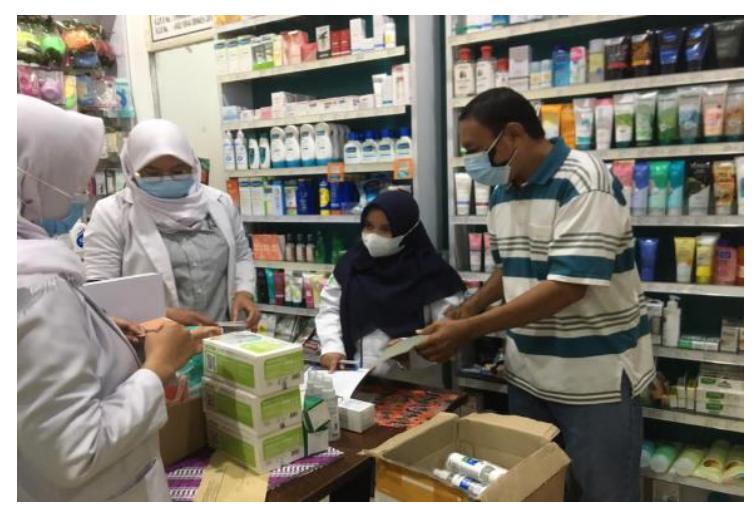

Gambar 1. Peserta Kegiatan

Pelaksanaan kegiatan diawali registrasi masyarakat kegiatan pengabdian kepada masyarakat di apotek century dilanjutkan dengan pembukaan kegiatan oleh store manager apotek century. Sebelum dilakukan penyuluhan, peserta diberikan kuisioner pre test untuk menilai kemampuan sebelum kegiatan penyuluhan. Kegiatan pre test dilaksanakan pada hari kamis, 1 Juli 2021 pukul 16.00 WIT bertempat di apotek century terlihat pada gambar 2. Selama kegiatan berlangsung peserta yang hadir pada pengisian pre test, hadir juga pada post test (absen terlampir. Soal pre test disesuaikan dengan bahasa masyarakat awam yang terdiri dari 10 soal dengan pilihan jawaban menggunakan skala guttman. Hasil dari pre test ini bermanfaat untuk mengetahui sejauhmana pemahaman masyarakat sebelum diberikan penyuluhan.

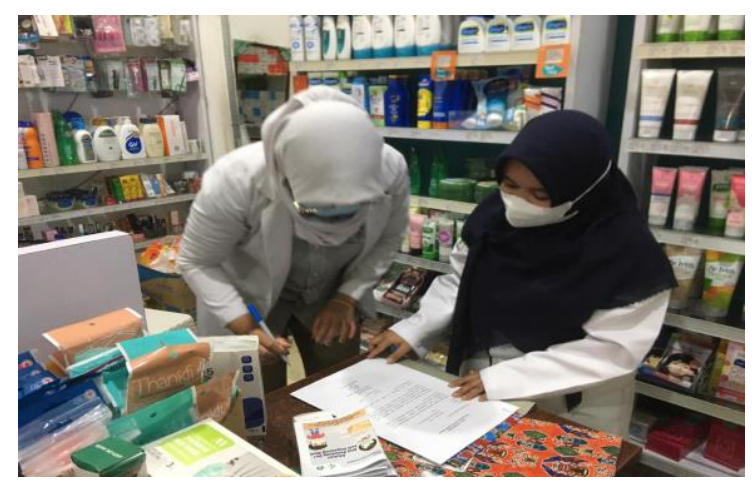

Gambar 2. Peserta Mengisi Kuesioner Pre dan Post Test
Setelah dilakukan pengisian kuesioner pre test, tim pengabdi melakukan penyuluhan. Metode yang digunakan adalah ceramah dan Tanya jawab terlihat pada gambar 3 . Materi pada penyuluhan adalah pengenalan alat pelindung diri, kegunaan alat pelindung diri, material yang digunakan pada alat pelindung diri, tahapan dispensing obat, cara penggunaan alat pelindung diri saat dispensing obat, penyimpanan alat pelindung diri dan langkah penting dalam pencegahan virus di apotek.

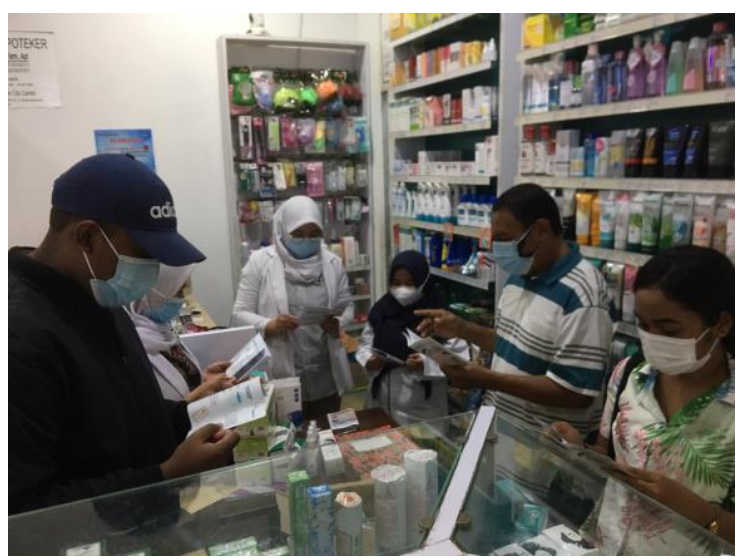

Gambar 3. Penyuluhan

Media booklet yang menarik sebagai media untuk meningkatkan pengetahuan dan sikap masyarakat. Desain booklet dibuat semenarik mungkin dan memilih kalimat yang mudah dipahami oleh masyarakat agar masyarakat mampu menyerap ilmu yang ada dalam booklet tersebut. Materi booklet menampilkan jenis-jenis alat pelindung diri dan penggunaannya saat dispensing obat terlihat pada gambar 4 .

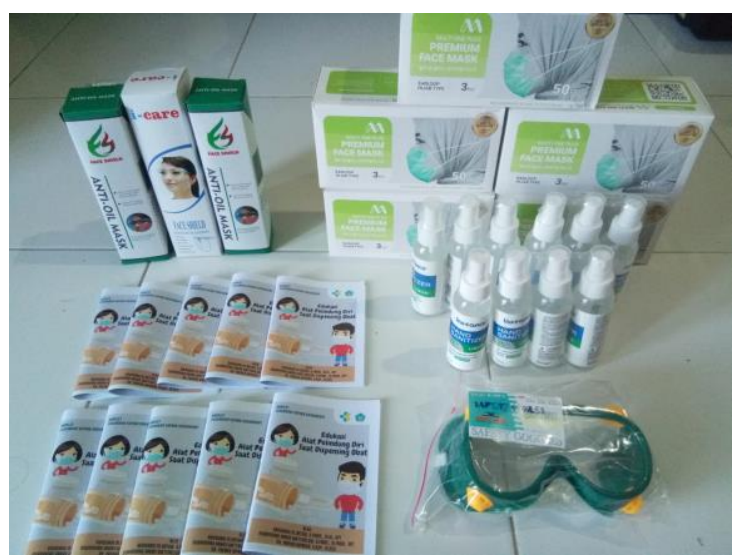

Gambar 4. Alat Pelindung Diri dan Booklet

Kegiatan terakhir adalah peserta diberikan kuisioner post test untuk menilai kemampuan sesuadah kegiatan penyuluhan. Kegiatan post test dilaksanakan pada pukul 18.00 WIT bertempat di apotek century terlihat 
pada gambar 2. Soal post test disesuaikan dengan bahasa masyarakat awam yang terdiri dari 10 soal dengan pilihan jawaban menggunakan skala guttman. Hasil dari post test ini bermanfaat sebagai evaluasi setelah diberikan penyuluhan yang diharapkan dapat meningkatkan pengetahuan tentang alat pelindung diri saat dispensing obat di apotek century

Hasil dari kuesioner pre dan post test dapat dilihat pada tabel 1 . Secara statistik hasil dari pelaksanaan pre test dan post test diuji analisis dengan menggunakan analisis paired sample t-test dengan hasil perolehan adalah nilai sig (2-tailed) sebesar $0,000<0,05$, maka terdapat perbedaan yang signifikan antara pre test dan post test. Hal ini mengindikasikan bahwa edukasi alat pelindung diri saat dispensing obat sangat mempengaruhi tingkat pengetahuan masyarakat. Terjadi peningkatan pengetahuan setelah dilakukan kegiatan penyuluhan.

Tabel 1. Nilai Hasil Pengetahuan Pre Test dan Post Test

\begin{tabular}{ccc}
\hline NO & PRE TEST & POST TEST \\
\hline 1 & 8 & 10 \\
2 & 7 & 10 \\
3 & 4 & 7 \\
4 & 5 & 8 \\
5 & 4 & 8 \\
6 & 6 & 10 \\
7 & 5 & 9 \\
8 & 8 & 9 \\
9 & 8 & 9 \\
10 & 5 & 9 \\
\hline
\end{tabular}

Penggunaan alat pelindung diri harus menjadi kewajiban dan kebiasaan tenaga kefarmasian sebagai perlindungan terakhir dalam upaya pencegahan virus. Penggunaan alat pelindung diri dapat mengurangi resiko paparan penularan penyakit pada tenaga kefarmasian (Harwanti, 2009). Dari hasil survei di lapangan, masih ada sebagian tenaga kefarmasian yang tidak memakai alat pelindung diri secara lengkap ketika melakukan dispensing obat yang mempunyai potensi dan faktor bahaya tertentu. Hal ini disebabkan karena tenaga kefarmasian merasa tidak nyaman dan tidak leluasa dalam penggunaan alat pelindung diri tersebut. Diharapkan dengan adanya kegiatan pengabdian masyarakat ini, para tenaga kefarmasian memiliki tingkat pengetahuan yang lebih baik, kemandirian dan kesadaran diri masing-masing terhadap pentingnya penggunaan alat pelindung diri saat dispensing obat dan bisa terlaksana dengan baik. Penggunaan alat pelindung diri merupakan usaha terakhir untuk mengurangi resiko secara maksimal dalam upaya pencegahan virus.

\section{SIMPULAN DAN SARAN}

Berdasarkan hasil pengabdian
masyarakat dengan program kemitraan masyarakat yang dilaksanakan di apotek century, maka dapat disimpulkan bahwa terdapat peningkatan antara sebelum dan sesudah pemberian edukasi alat pelindung diri saat dispensing obat sebagai upaya pencegahan virus

Untuk meningkatkan kemandirian masyarakat dalam penggunaan alat pelindung diri, maka saran yang dapat disampaikan adalah perlu adanya komitmen bersama antara store manager apotek dengan 10 orang masyarakat yang telah diberikan pengetahuan edukasi alat pelindung diri saat dispensing obat dalam meningkatkan kemandirian, kesadaran dan tetap menjaga protocol kesehatan sebagai upaya pencegahan virus kepada semua masyarakat disekitarnya

\section{UCAPAN TERIMA KASIH}

Ucapan terima kasih tim sampaikan kepada pihak Poltekkes Kemenkes Maluku dan Apotek Century yang terlibat dalam kegiatan pengabdian masyarakat melalui edukasi alat pelindung diri saat dispensing obat melalui pembagian booklet sebagai upaya pencegahan virus.

\section{DAFTAR RUJUKAN}

Aziza, W., Aipassa, F., \& Natsir, R. M. (2020). Swamedikasi Pemberian Antiseptik Dan Penyuluhan Pencegahan Penyakit Rabies Dengan Media Booklet. SELAPARANG Jurnal Pengabdian Masyarakat Berkemajuan, 4(1), 496. https://doi.org/10.31764/jpmb.v4i1.3255

Harwanti, N. (2009). Pemakaian Alat Pelindung Diri Dalam Memberikan Perlindungan Bagi Tenaga Kerja di Instalasi Rawat Inap I RSUP Dr. Sardjito Yogyakarta. Skripsi, Surakarta.

Kemenkes. (2020). Pedoman kesiapan menghadapi COVID-19. Pedoman Kesiapan Menghadapi COVID-19, 0-115.

Kementerian Kesehatan RI. (2014). Standar Pelayanan Kefarmasian Di Apotek. In Peraturan Menteri Kesehatan RI Nomor 35 (Vol. 8, Issue 33).

Kementerian Kesehatan RI. (2020). Surat Edaran Kemenkes 335 Nomor HK.02.01MENKES/335/2020 Protokol Pencegahan COVID-19 Tempat Kerja Sektor Jasa dan Perdagangan.

Kusuma Putra, G. L. A., Nandaryani, N. W., \& Adnyana Yasa, G. P. P. (2020). 
Perancangan Desain Sebagai Sarana Informasi Pencegahan Virus Corona. Jurnal Lentera Widya, 1(2), 31-38. https://doi.org/10.35886/lenterawidya.v1i 2.102

Rachmawati, H., Hidayati, I. R., Ermawati, D., Astuti, E. J., Pengajar, S., Farmasi, J., \& Kesehatan, F. I. (2013). Pendirian Pusat Pelayanan Informasi Obat Untuk Peningkatan Pelayanan Kefarmasian Dan Sarana Edukasi di Apotek UMM Medical Center. Jurnal UMM, 10, 27-32.

Triguno, Y., Ayu, P. L., Wardana, K. E. L., Raningsih, N. M., \& Arlinayanti, K. D. (2020). Edukasi Pencegahan Penularan Covid 19 Serta Dukungan Kesehatan Jiwa dan Psikososial Pada Pengemudi Ojek Online. Jurnal Peduli Masyarakat, 2, 5964. 